\title{
New sesquiterpene hydroquinones from the Caribbean sponge Aka coralliphagum
}

\author{
Qun Göthel and Matthias Köck ${ }^{*}$
}

\section{Full Research Paper}

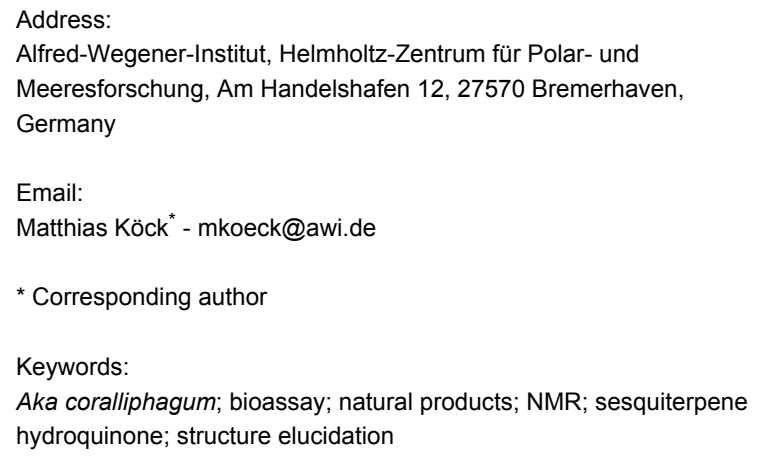

\begin{abstract}
Four new sulfated sesquiterpene hydroquinones siphonodictyals E1-E4 (1-4) and cyclosiphonodictyol A (5) were isolated from a sample of the Caribbean sponge Aka coralliphagum collected off the coast of San Salvador in the Bahamas. The structures of the new compounds were elucidated on the basis of mass spectrometric and NMR spectroscopic analysis. Compounds 1-4 are derivatives of siphonodictyal E (9). Siphonodictyal E4 (4) exhibited mild antiproliferation activity against L929 mouse fibroblast, KB-31 epidermoid carcinoma, and MCF-7 breast cancer cell lines, while siphondictyal E3 (3) and cyclosiphonodictyol A (5) showed moderate activity against Gram-positive bacteria.
\end{abstract}

\section{Introduction}

Aka coralliphagum (Siphonodictyon coralliphagum) is known to have four distinct morphological forms: forma typica, f. tubulosa, f. obruta, and f. incrustans [1]. This sponge has the ability to burrow into live coral heads, leaving only the oscular chimney protruding (typica) or the flat crusts (incrustans) exposed. The oscular chimneys or the flat crusts are encircled by a so-called "dead zone" which protects the sponge from overgrowth [2]. Sullivan and Faulkner have proposed that the coral polyps are killed by the viscous mucus containing the toxic secondary metabolites which are produced by the sponge

tissue [3]. This ecological observation inspired the chemical investigation of this sponge by different research groups. Thus many secondary metabolites have been reported, such as the sesquiterpene phenolic aldehydes, siphonodictyals B, C, D, E, the monosulfated siphonodictyols $\mathrm{G}$ and $\mathrm{H}$, the disulfated siphonodictyal B3, and siphonodictyoic acid $[2,4,5]$. The sponge under our investigation is of the growth form incrustans, which was collected off the coast of San Salvador in the Bahamas. Fractionation of the aqueous $n$-BuOH extract yielded the new compounds siphonodictyals E1-E4 (1-4) and 
cyclosiphonodictyol A (5). In this article, we describe the isolation, structural elucidation, and bioactivity of compounds 1-5 from the Aka growth form incrustans, as well as discuss the biosynthetic pathway of related compounds.

\section{Results and Discussion}

The aqueous $n-\mathrm{BuOH}$ extract from Aka coralliphagum was subjected to solvent partitioning, followed by gel chromatography and reversed phase (C18) HPLC to yield siphonodictyals E1-E4 (1-4) and cyclosiphonodictyol A (5) (Figure 1). The structure elucidation was based on $1 \mathrm{D}$ and $2 \mathrm{D}$ NMR as well as HRMS-ESI(-) experiments. The ${ }^{1} \mathrm{H}$ and ${ }^{13} \mathrm{C}$ NMR chemical shifts for the five new compounds are given in Table 1.

Siphonodictyal E1 (1) was identified by NMR data and its accurate mass of $598.1338[\mathrm{M}+\mathrm{Na}-2 \mathrm{H}]^{-}$which indicated the molecular formula $\mathrm{C}_{24} \mathrm{H}_{35} \mathrm{NO}_{11} \mathrm{~S}_{2}$. Comparison of the NMR data of 1 and siphonodictyal E (9, Figure 2) [2] revealed the presence of the identical sesquiterpene acyclic chain with one of the terminal methyl groups oxidized to a carboxylic acid. More- over, the diagnostic values for $\mathrm{C}-14(\delta 15.7)$ and $\mathrm{C}-15(\delta 15.9)$ confirmed a common $6 E, 10 E$ double-bond geometry [6,7]. The NMR spectral data also suggested a similar aromatic ring system as in siphonodictyal E (9). Moreover, the ${ }^{1} \mathrm{H},{ }^{1} \mathrm{H}-\mathrm{COSY}$ correlation between the two methylene groups $\mathrm{CH}_{2}-23$ and $\mathrm{CH}_{2}$-24 as well as the ${ }^{1} \mathrm{H},{ }^{13} \mathrm{C}-\mathrm{HMBC}$ correlations from $\mathrm{H}-22$ ( $\delta$ 8.67) to C-18 ( $\delta 144.0), \mathrm{C}-19$ ( $\delta 156.4), \mathrm{C}-20$ ( $\delta 110.9), \mathrm{C}-21$ ( $\delta$ 141.8), and C-23 ( $\delta$ 51.2) further indicated that an iminoethanesulfonic acid is connected to the aromatic ring system in 1 (Figure 3), as in siphonodictyal B1 (6, Figure 2) [5].

Examination of the NMR data for siphonodictyal E2 (2) revealed a high degree of similarity with the data reported for siphonodictyal E (9). However, the molecular ion peak of compound 2 was shown at $m / z 469.1534\left([\mathrm{M}-\mathrm{H}]^{-} \mathrm{C}_{22} \mathrm{H}_{29} \mathrm{O}_{9} \mathrm{~S}\right)$, which has $80 \mathrm{amu}$ more than that of $\mathbf{9}$, indicating an additional sulfate ester group in compound 2 . The ${ }^{1} \mathrm{H},{ }^{13} \mathrm{C}-\mathrm{HMBC}$ correlations from 18-OH to $\mathrm{C}-17$ ( $\delta 122.8), \mathrm{C}-18$ ( $\delta 141.8)$, and $\mathrm{C}-19$ $(\delta 147.8)$ as well as from $19-\mathrm{OH}$ to $\mathrm{C}-18$ ( $\delta 141.8), \mathrm{C}-19$ $(\delta 147.8)$, and $\mathrm{C}-20(\delta 115.5)$ indicated that $\mathrm{C}-18$ and $\mathrm{C}-19$ are<smiles>CC(=CCc1cc(O)c(O)c(/C=N\CCS(=O)(=O)O)c1OS(=O)(=O)O)CCCC(C)C(=O)O</smiles>

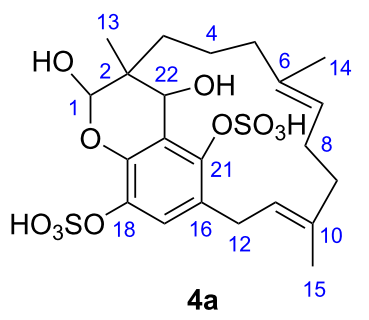<smiles>C/C(=C\CCCC(C)C(=O)O)CC/C=C(\C)CC/C=C(\C)C(=O)O</smiles>

2<smiles>CCCCC(C)=CCc1cc(OS(=O)(=O)O)c(OS(=O)(=O)O)c2c1OC(O)C2(C)CCC=C(C)CO</smiles>

$4 b$<smiles>CC(C)=CCC/C(C)=C/CC/C(C)=C/Cc1cc(OS(=O)(=O)O)c(O)c(OS(=O)(=O)O)c1C=O</smiles>

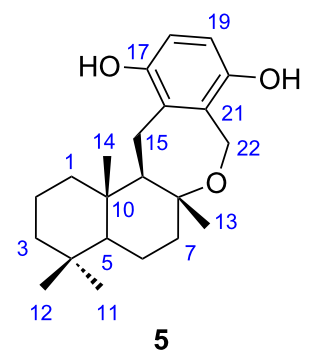

Figure 1: Structures of the new compounds siphonodictyals E1-E4 (1-4) and cyclosiphonodictyol A (5) isolated from the sponge Aka coralliphagum. Since the structure of siphonodictyal E4 (4) could not be unambiguously assigned, the two possible constitutional isomers (4a and $\mathbf{4 b}$ ) are shown. 
Table 1: NMR data of compounds 1-5 $\left(\delta_{\mathrm{C}} 150 \mathrm{MHz}, \delta_{\mathrm{H}} 600 \mathrm{MHz}\right.$ in DMSO- $\left.d_{6}\right) .^{a}$

\begin{tabular}{|c|c|c|c|c|c|c|c|c|c|c|}
\hline \multirow[t]{2}{*}{ No. } & \multicolumn{2}{|r|}{1} & \multicolumn{2}{|r|}{2} & \multicolumn{2}{|r|}{3} & \multicolumn{2}{|r|}{4} & \multicolumn{2}{|r|}{5} \\
\hline & $\delta_{C}$ & $\delta_{H}$ & $\delta_{C}$ & $\delta_{H}$ & $\delta_{C}$ & $\delta_{\mathrm{H}}$ & $\delta_{C}$ & $\delta_{H}$ & $\delta_{C}$ & $\delta_{H}$ \\
\hline \multirow[t]{2}{*}{1} & 177.8 & - & 177.5 & - & 25.5 & $1.62(\mathrm{~s})$ & 96.2 & $5.42(\mathrm{~s})$ & 39.4 & $0.76(\mathrm{~m})$ \\
\hline & & & & & & & & & & $1.91(\mathrm{~m})$ \\
\hline \multirow[t]{2}{*}{2} & 38.7 & $2.28(\mathrm{~m})$ & 38.6 & $2.28(\mathrm{~m})$ & 130.6 & - & 37.3 & - & 18.2 & $1.38(\mathrm{~m})$ \\
\hline & & & & & & & & & & $1.60(\mathrm{~m})$ \\
\hline \multirow[t]{2}{*}{3} & 32.9 & $1.25(\mathrm{~m})$ & 32.8 & $1.25(\mathrm{~m})$ & 124.2 & $5.05(\mathrm{t}, 7.1)$ & 31.4 & $1.03(\mathrm{~m})$ & 41.6 & $\begin{array}{l}1.08(\mathrm{dt}, 4.0 \\
13.5)\end{array}$ \\
\hline & & $1.47(\mathrm{~m})$ & & $1.47(\mathrm{~m})$ & & & & $1.13(\mathrm{~m})$ & & $1.33(\mathrm{~m})$ \\
\hline \multirow[t]{2}{*}{4} & 24.9 & $1.32(\mathrm{~m})$ & 24.9 & $1.31(\mathrm{~m})$ & 26.3 & $2.00(\mathrm{~m})$ & 22.1 & $0.56(\mathrm{~m})$ & 33.1 & - \\
\hline & & & & & & & & $1.11(\mathrm{~m})$ & & \\
\hline \multirow[t]{2}{*}{5} & 38.9 & $1.91(\mathrm{~m})$ & 39.4 & $1.91(\mathrm{t}, 6.9)$ & 39.3 & $1.92(\mathrm{~m})$ & 39.3 & $1.28(\mathrm{~m})$ & 55.4 & $0.83(\mathrm{~m})$ \\
\hline & & & & & & & & $1.75(\mathrm{~m})$ & & \\
\hline \multirow[t]{2}{*}{6} & 134.4 & - & 134.4 & - & 134.4 & - & 134.9 & - & 19.8 & $1.58(\mathrm{~m})$ \\
\hline & & & & & & & & & & $1.60(\mathrm{~m})$ \\
\hline \multirow[t]{2}{*}{7} & 124.0 & $5.09(\mathrm{t}, 6.5)$ & 124.0 & $5.09(\mathrm{t}, 6.8)$ & 124.0 & $5.09(\mathrm{t}, 7.1)$ & 121.7 & $4.52(\mathrm{t}, 5.9)$ & 40.1 & $1.43(\mathrm{~m})$ \\
\hline & & & & & & & & & & $1.60(\mathrm{~m})$ \\
\hline \multirow[t]{2}{*}{8} & 26.2 & $2.06(\mathrm{~m})$ & 26.2 & $2.06(\mathrm{~m})$ & 26.2 & $2.06(\mathrm{~m})$ & 23.8 & $1.89(\mathrm{~m})$ & 78.5 & - \\
\hline & & & & & & & & $2.01(\mathrm{~m})$ & & \\
\hline 9 & 40.1 & $1.98(\mathrm{~m})$ & 39.8 & $1.99(\mathrm{t}, 7.2)$ & 40.1 & $1.97(\mathrm{~m})$ & 39.0 & $1.92(\mathrm{~m})$ & 58.1 & $1.32(\mathrm{~m})$ \\
\hline 10 & 134.5 & - & 135.4 & - & 135.5 & - & 131.9 & - & 38.2 & - \\
\hline 11 & 123.7 & $5.19(\mathrm{t}, 7.2)$ & 122.9 & $5.21(\mathrm{t}, 7.2)$ & 122.6 & $5.21(\mathrm{t}, 7.0)$ & 125.7 & $5.10(t, 7.9)$ & 33.1 & $0.83(\mathrm{~s})$ \\
\hline \multirow[t]{2}{*}{12} & 27.2 & $3.25(\mathrm{~d}, 3.4)$ & 26.9 & $3.33^{b, c}$ & 27.1 & $3.35^{\mathrm{b}, \mathrm{c}}$ & 29.8 & $\begin{array}{l}2.58(\mathrm{dd}, 6.8 \\
12.6)\end{array}$ & 21.2 & 0.78 (s) \\
\hline & & & & & & & & $\begin{array}{l}3.99(\mathrm{dd}, 9.6 \\
12.4)\end{array}$ & & \\
\hline 13 & 17.0 & $1.01(\mathrm{~d}, 6.6)$ & 17.0 & $1.01(\mathrm{~d}, 6.9)$ & 17.6 & $1.54(\mathrm{~s})$ & 19.9 & $1.04(\mathrm{~s})$ & 21.6 & $1.31(\mathrm{~s})$ \\
\hline 14 & 15.7 & $1.53(\mathrm{~s})$ & 15.6 & $1.53(\mathrm{~s})$ & 16.0 & $1.55(\mathrm{~s})$ & 17.2 & $1.36(\mathrm{~s})$ & 15.3 & 0.79 (s) \\
\hline \multirow[t]{2}{*}{15} & 15.9 & 1.65 (s) & 15.9 & $1.66(\mathrm{~s})$ & 15.8 & $1.66(\mathrm{~s})$ & 15.1 & 1.62 (s) & 20.8 & $\begin{array}{l}2.33(\mathrm{dd}, 9.6 \\
15.5)\end{array}$ \\
\hline & & & & & & & & & & $3.06(d, 15.5)$ \\
\hline 16 & 120.5 & - & 125.9 & - & 125.5 & - & 126.5 & - & 129.9 & - \\
\hline 17 & 117.7 & $6.50(\mathrm{~s})$ & 122.8 & $6.84(\mathrm{~s})$ & 129.5 & 7.48 (s) & 120.8 & 7.19 (s) & 146.4 & - \\
\hline 18 & 144.0 & - & 141.8 & - & 137.7 & - & 137.2 & - & 113.7 & $6.45(d, 8.6)$ \\
\hline 19 & $156.4^{c}$ & - & 147.8 & - & 151.3 & - & 143.2 & - & 112.4 & $6.38(d, 8.6)$ \\
\hline 20 & $110.9^{c}$ & - & 115.5 & - & 115.9 & - & 120.3 & - & 146.5 & - \\
\hline 21 & $141.8^{\mathrm{C}}$ & - & 144.5 & - & 148.2 & - & 142.9 & - & 127.7 & - \\
\hline \multirow[t]{2}{*}{22} & 164.6 & $8.67(\mathrm{~s})$ & 197.2 & $10.10(\mathrm{~s})$ & 196.6 & 10.11 (s) & 65.3 & $4.44(\mathrm{~s})$ & 56.7 & $4.50(\mathrm{~d}, 15.0)$ \\
\hline & & & & & & & & & & $4.64(\mathrm{~d}, 15.0)$ \\
\hline 23 & $51.2^{d}$ & $3.83(t, 6.5)$ & & & & & & & & \\
\hline 24 & $51.2^{d}$ & $2.82(\mathrm{t}, 6.2)$ & & & & & & & & \\
\hline $1-\mathrm{OH}$ & & & & & & & & 7.07 (bs) & & \\
\hline $18-\mathrm{OH}$ & & & & 9.09 & & & & & & \\
\hline $19-\mathrm{OH}$ & & & & 11.37 & & & & & & \\
\hline 22-OH & & & & & & & & 5.09 (bs) & & \\
\hline
\end{tabular}

å are given in ppm (reference: DMSO- $d_{6}, 2.50$ ppm, 39.52 ppm), coupling constants are given in Hz; assignments were confirmed by $2 \mathrm{D}$ NMR experiments (COSY, HSQC, HMBC). ${ }^{b}$ Overlap with water peak. ${ }^{\circ}$ Chemical shifts were obtained from HMBC spectra. ${ }^{\mathrm{d} O v e r l a p}$ with each other. 
<smiles>CC1CC[C@H](C)[C@@]2(C)CCC[C@](C)(O)[C@@H]12</smiles>

6<smiles>CC1CCC2C(C)(C)CCCC2(C)/C1=C\c1cc(O)c(O)c(C=O)c1C(=O)O</smiles>

7<smiles>CC1CCC2C(C)(C)CCC[C@]2(C)/C1=C\c1cc(OS(=O)(=O)O)c(O)c(C=O)c1OS(=O)(=O)O</smiles>

8<smiles>CC(=CCc1cc(O)c(O)c(C=O)c1O)CCC=C(C)CCCC(C)C(=O)O</smiles>

9

Figure 2: Structures of the related known compounds siphonodictyal B1 (6), siphonodictyal B2 (7), siphonodictyal B3 (8), and siphonodictyal E (9) from the sponge Aka coralliphagum.

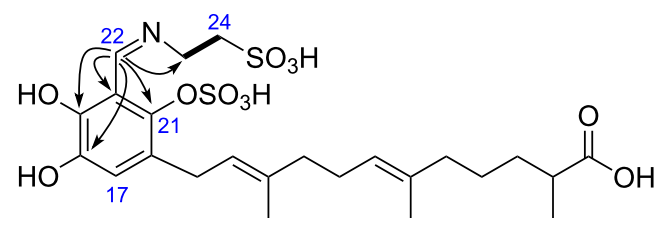

Figure 3: Selected ${ }^{1} \mathrm{H},{ }^{13} \mathrm{C}-\mathrm{HMBC}$ correlations $(\mathrm{H} \rightarrow \mathrm{C})$ and ${ }^{1} \mathrm{H},{ }^{1} \mathrm{H}-$ COSY correlation (bold line) observed for siphonodictyal E1 (1).

connected to hydroxy groups rather than sulfate ester groups (Figure 4). Thus, the sulfate ester group should be at position C-21. Furthermore, the ${ }^{13} \mathrm{C}$ NMR chemical shifts of the three constitutional isomers $\mathbf{2}$-I to 2 -III were calculated using an increment system (Table 2) with additional values for sulfate esters published by Ragan [8]. These calculations (Table 3) allowed us to confirm the position of the sulfate moiety (2-I, Figure 5). The comparison of the NMR data of $\mathbf{2}$ and siphonodictyal B2 (7, Figure 2) [5] further confirmed the identity of the aromatic moiety of both compounds.

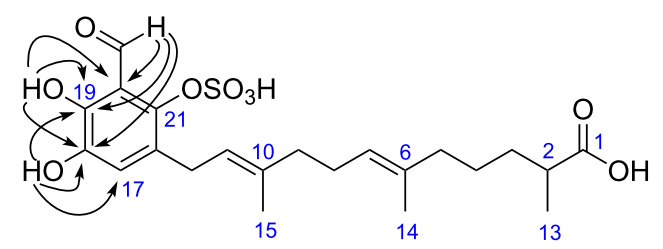

Figure 4: Selected ${ }^{1} \mathrm{H},{ }^{13} \mathrm{C}-\mathrm{HMBC}$ correlations $(\mathrm{H} \rightarrow \mathrm{C})$ observed for siphonodictyal E2 (2).

\begin{tabular}{|c|c|c|c|c|}
\hline $\begin{array}{l}\text { Functional } \\
\text { group }\end{array}$ & $i[\mathrm{ppm}]$ & o [ppm] & $m$ [ppm] & $p$ [ppm] \\
\hline $\mathrm{CHO}$ & 8.4 & 1.2 & 0.5 & 5.7 \\
\hline $\mathrm{OH}$ & 26.9 & -12.8 & 1.4 & -7.4 \\
\hline Allyl & 15.3 & 0 & 0.2 & -2.4 \\
\hline $\mathrm{OSO}_{3} \mathrm{H}$ & 22.0 & -7.0 & 1.5 & -2.0 \\
\hline
\end{tabular}

The HRMS-ESI(-) spectrum for siphonodictyal E3 (3) displayed the pseudomolecular ion peak $[\mathrm{M}+\mathrm{Na}-2 \mathrm{H}]^{-}$at $\mathrm{m} / \mathrm{z}$ 539.1046, indicating the molecular formula $\mathrm{C}_{22} \mathrm{H}_{30} \mathrm{O}_{10} \mathrm{~S}_{2}$. The ${ }^{13} \mathrm{C}$ NMR spectrum contained six olefinic signals in addition to the aromatic signals, and the ${ }^{1} \mathrm{H}$ NMR spectrum contained four olefinic methyl signals at $\delta 1.62(\mathrm{~s}), \delta 1.54(\mathrm{~s}), \delta 1.55(\mathrm{~s})$, and $\delta 1.66(\mathrm{~s})$, which suggested a sesquiterpene side chain containing three trisubstituted olefinic bonds. The two sulfate ester groups were assigned to attach to C-18 and C-21 after comparison of the NMR data of the aromatic moieties of $\mathbf{3}$ with those of siphonodictyal B3 (8, Figure 2). Nevertheless, the results of the increment calculations using the values for sulfate esters from Ragan [8] clearly favours the isomer 3-I (Figure 5), which further supports our proposed structure.

The HRMS-ESI(-) spectrum for siphonodictyal E4 (4) showed the pseudomolecular ion peak $[\mathrm{M}+\mathrm{Na}-2 \mathrm{H}]^{-}$at $m / z 555.0954$, confirmed its molecular formula as $\mathrm{C}_{22} \mathrm{H}_{30} \mathrm{O}_{11} \mathrm{~S}_{2}$, corresponding to eight double bond equivalents. The sesquiterpenoid moiety of the molecule contained two trisubstituted olefinic 


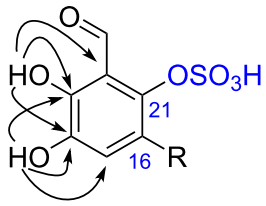

2-I: $16.7 \mathrm{ppm}$<smiles>[R9]Oc1cc([R])c(OS(=O)(=O)O)c(C=O)c1O</smiles>

3-I: $16.2 \mathrm{ppm}$<smiles>[R]c1cc(O)c(O[Na])c(C=O)c1O</smiles>

2-II: 25.9 ppm<smiles>[R]c1cc(O)c(OS(=O)(=O)O)c(C=O)c1OS(=O)(=O)O</smiles>

3-II: 50.0 ppm<smiles>[R]c1cc(OS(=O)(=O)O)c(O)c(C=O)c1O</smiles>

2-III: $33.1 \mathrm{ppm}$<smiles>[R]c1cc(O[18OH])c(O)c(C=O)c1O</smiles>

3-III: 25.4 ppm

Figure 5: Possible constitutions for the aromatic moieties of siphonodictyals E2 (2) and E3 (3) (sum over all $\Delta \delta\left({ }^{13} \mathrm{C}\right)$ : 2-I $16.7 \mathrm{ppm}, \mathbf{2}-\mathrm{II} 25.9 \mathrm{ppm}, \mathbf{2}-\mathrm{III}$ $33.1 \mathrm{ppm}, 3-\mathrm{I} 16.2 \mathrm{ppm}, 3-\mathrm{II} 50.0 \mathrm{ppm}, 3-\mathrm{III} 25.4 \mathrm{ppm}$ ); plain arrows in 2-I showed the HMBC correlations from 18-OH and 19-OH to the aromatic carbons; dashed arrows in 2-II and 2-III indicate HMBC correlations which would be expected.

Table 3: Results of the increment calculations for the aromatic moiety of the three constitutional proposals of siphonodictyal E2 (2) and siphonodictyal E3 (3).

\begin{tabular}{|c|c|c|c|c|}
\hline Carbon No. & Siphonodictyal E2 (2) & $2-1$ & $2-I I$ & $2-I I I$ \\
\hline 16 & 125.9 & $131.3(5.4)$ & $130.9(5.0)$ & $125.6(0.3)$ \\
\hline 17 & 122.8 & $124.3(1.5)$ & $124.3(1.5)$ & $130.0(7.2)$ \\
\hline 18 & 141.8 & $141.3(0.5)$ & $141.7(0.1)$ & $131.0(10.8)$ \\
\hline 19 & 147.8 & $142.9(4.9)$ & $137.9(9.9)$ & $148.6(0.8)$ \\
\hline 20 & 115.5 & $118.7(3.2)$ & $118.7(3.2)$ & $113.0(2.5)$ \\
\hline 21 & 144.5 & $145.7(1.2)$ & $150.7(6.2)$ & $156.0(11.5)$ \\
\hline$\Sigma[\mathrm{ppm}]$ & & 16.7 & 25.9 & 33.1 \\
\hline Carbon No. & Siphonodictyal E3 (3) & $3-1$ & $3-11$ & $3-I I I$ \\
\hline 16 & 125.5 & $131.4(5.9)$ & $136.7(11.2)$ & $131.0(5.5)$ \\
\hline 17 & 129.5 & $130.1(0.6)$ & $124.4(5.1)$ & $130.1(0.6)$ \\
\hline 18 & 137.7 & $136.4(1.3)$ & $147.1(9.4)$ & $136.8(0.9)$ \\
\hline 19 & 151.3 & $148.7(2.6)$ & $138.0(13.3)$ & $143.7(7.6)$ \\
\hline 20 & 115.9 & $118.8(2.9)$ & $124.5(8.6)$ & $118.8(2.9)$ \\
\hline 21 & 148.2 & $151.1(2.9)$ & $145.8(2.4)$ & $156.1(7.9)$ \\
\hline$\Sigma[\mathrm{ppm}]$ & & 16.2 & 50.0 & 25.4 \\
\hline
\end{tabular}

bonds $(\delta 121.7, \delta 125.7, \delta 131.9, \delta 134.9)$ and a hemiacetal carbon $(\delta 96.2)$ at one terminus which differed from the acyclic side chain in $\mathbf{1}$ and $\mathbf{2}$. The remaining six carbon signals in the downfield region of the ${ }^{13} \mathrm{C}$ NMR spectrum belonged to the tetrasubstituted aromatic ring system. In contrast to $\mathbf{1}$ and $\mathbf{2}$, compound 4 contained an oxymethine group $\left(\mathrm{CH}-22, \delta_{\mathrm{C}} 65.3\right.$, $\delta_{\mathrm{H}} 4$.44) which connected the sesquiterpene chain with the aromatic ring. This is supported by the six/seven HMBC correlations from $\mathrm{H}-22$ to $\mathrm{C}-1$ ( $\delta$ 96.2), $\mathrm{C}-2$ ( $\delta 37.3), \mathrm{C}-3$ ( $\delta 31.4)$,
C-13 ( $\delta$ 19.9), C-19 ( $\delta$ 143.2) / C-21 ( $\delta$ 142.9), and C-20 $(\delta$ 120.3). The HMBC correlations from $\mathrm{H}-12$ ( $\delta 2.58,3.99)$ to $\mathrm{C}-17(\delta 120.8)$ and $\mathrm{C}-21$ and from $\mathrm{H}-17(\delta 7.19)$ to $\mathrm{C}-18$ $(\delta$ 137.2) confirmed the position of the unsubstituted $\mathrm{CH}-17$ as shown in the proposed structure (Figure 6). Since the very weak HMBC correlation from $\mathrm{H}-1$ to $\mathrm{C}-19$ or $\mathrm{C}-21$ could not be unambiguously assigned, the constitutional isomers with respect to the position of the oxygen bridge $\mathbf{4 a}$ and $\mathbf{4 b}$ (Figure 1) are in accordance with the NMR data. This is the first compound 

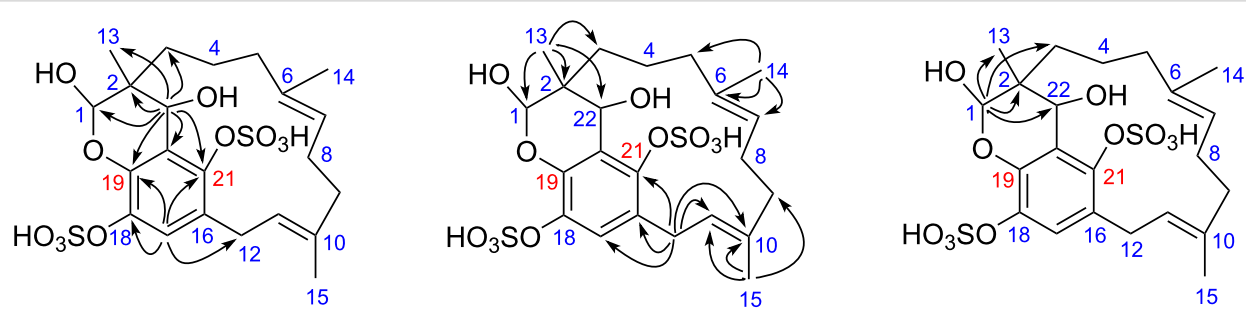

Figure 6: Selected ${ }^{1} \mathrm{H},{ }^{13} \mathrm{C}-\mathrm{HMBC}$ correlations $(\mathrm{H} \rightarrow \mathrm{C})$ observed for siphonodictyal E4 (4a).

isolated from this sponge which contains a macrocycle. Moreover, this macrocycle could probably be formed by an aldol addition from a precursor with an acyclic sesquiterpene side chain (Figure 7). The aromatic ring system of proposed precursor 3-ox in Figure 7 also appeared in the known compound siphonodictyal B3 (8) [5] isolated from the same sponge source as well as the newly identified compound $\mathbf{3}$. There are no similar compounds known which contained the aromatic ring system with two adjacent sulfate ester groups. Therefore, we assumed that the constitutional isomer $\mathbf{4 a}$ is more likely. The $\delta$ values of methyl carbons $\mathrm{C}-14$ and $\mathrm{C}-15$ below 20 ppm indicated the $E$ configuration of the double bonds C-6/C-7 and $\mathrm{C}-10 / \mathrm{C}-11$ of the isoprenoid chain [6,7]. Additionally, in the NOESY spectrum we could observe a weak correlation between $\mathrm{H}-22(\delta 4.44)$ and $\mathrm{H}-3(\delta 1.03)$ as well as between $\mathrm{H}-22(\delta 4.44)$ and $\mathrm{H}-13$ ( $\delta 1.04)$. Because of the overlapping of the proton signals of $\mathrm{H}-3$ and $\mathrm{H}-13$, this assignment is not unambiguous. Due to the flexibility of the macrocycle of $\mathbf{4}$ it was not possible to analyse the conformation of the pyrane. Therefore, the configurations at the centers $\mathrm{C}-1, \mathrm{C}-2$, and $\mathrm{C}-22$ could not be assigned. Further investigations are hindered by the fact that compound 4 easily degrades.
The HRMS-ESI(-) spectrum for cyclosiphonodictyol A (5) showed the pseudomolecular ion peak $[\mathrm{M}+\mathrm{Na}-2 \mathrm{H}]^{-}$at $\mathrm{m} / z$ 343.2292, confirmed its molecular formula as $\mathrm{C}_{22} \mathrm{H}_{32} \mathrm{O}_{3}$. The ${ }^{13} \mathrm{C}$ NMR spectrum displayed six signals in the area of aromatic carbon atoms and 16 signals in the aliphatic region. The ${ }^{1} \mathrm{H},{ }^{13} \mathrm{C}$-HSQC spectrum indicated four methyl and seven methylene groups. Two of these methylene groups connected directly to the aromatic ring system indicated by the ${ }^{1} \mathrm{H},{ }^{13} \mathrm{C}$ HMBC correlations H-15 $(\delta 2.33,3.06) \rightarrow$ C-16 ( $\delta$ 129.9), $\mathrm{C}-17(\delta 146.4)$, and $\mathrm{C}-21(\delta 127.7)$ as well as $\mathrm{H}-22(\delta 4.50$, $4.64) \rightarrow \mathrm{C}-16, \mathrm{C}-20(\delta 146.5)$, and $\mathrm{C}-21$. The sesquiterpene unit of 5 was identified by ${ }^{1} \mathrm{H},{ }^{1} \mathrm{H}-\mathrm{COSY}$ and ${ }^{1} \mathrm{H},{ }^{13} \mathrm{C}-\mathrm{HMBC}$ experiments. Furthermore, the HMBC correlations H-15 $\rightarrow$ C-8 $(\delta 78.5)$, C-9 ( $\delta 58.1$ ), and C-10 ( $\delta 38.2)$ confirmed the connection between $\mathrm{C}-15$ and $\mathrm{C}-9$ and the HMBC correlation $\mathrm{H}-22 \rightarrow$ $\mathrm{C}-8$ indicated the existence of the oxygen bridge between $\mathrm{C}-22$ and $\mathrm{C}-8$. The $p$-hydroquinone moiety was established on the basis of the ${ }^{1} \mathrm{H}$ and ${ }^{13} \mathrm{C}$ NMR chemical shifts as well as the HMBC correlations mentioned above, namely, H-15 $\rightarrow$ C-16, $\mathrm{C}-17, \mathrm{C}-21$; H-22 $\rightarrow \mathrm{C}-16, \mathrm{C}-20, \mathrm{C}-21$. The relative configuration was confirmed by a ROESY experiment. The observed ROESY correlations between H-12 and H-13, H-13 and H-15,

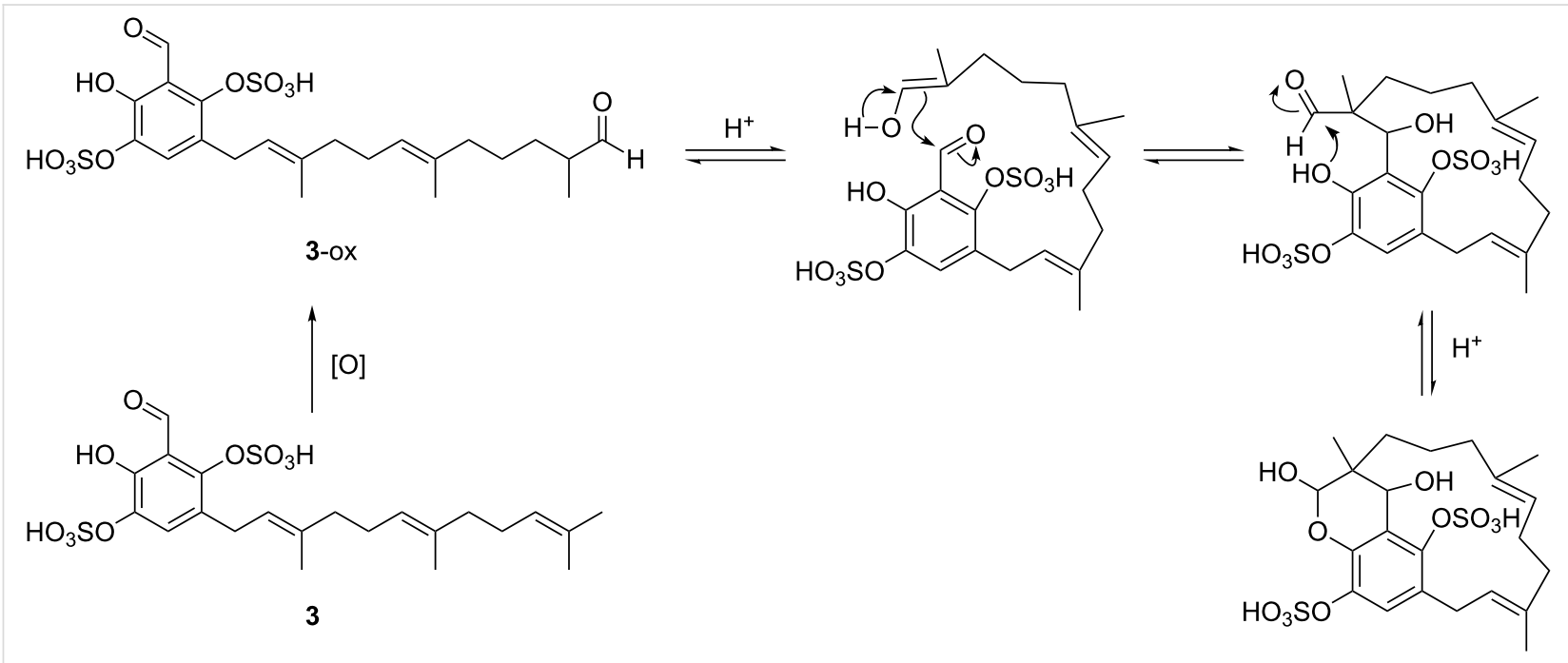


$\mathrm{H}-14$ and $\mathrm{H}-15$ suggested that the three methyl groups as well as $\mathrm{CH}_{2}-15$ are axial. Examination of the NMR data for 5 revealed a high degree of similarity with data reported for bis(sulfato)cyclosiphonodictyol A [10]. The difference concerned the absence of the two sulfate ester groups. Compound 5 could be the precursor of bis(sulfato)cyclosiphonodictyol A. Another possibility is that bis(sulfato)cyclosiphonodictyol A lost its sulfate ester group during the isolation procedure.

The new compounds were tested for antimicrobial activity against different Gram-positive and Gram-negative bacteria, fungi, and for antiproliferative activity. The results given in Table 4 show that siphonodictyal E3 (3) and cyclosiphonodictyol A (5) exhibited mild activity against the Gram-positive bacteria Staphylococcus aureus and Micrococcus luteus, while siphonodictyal E4 (4) show cytotoxic activity against the L929 mouse fibroblasts, KB-31 epidermoid carcinoma, and the breast cancer cell line MCF7, although none of them showed activity in the antimicrobial assays against Gram-negative bacteria and the fungus Candida albicans.

Many of the isolated compounds from Aka coralliphagum are bicyclic sesquiterpene hydroquinones. However, in the course of our investigation, three linear sesquiterpenes were isolated. From a biosynthetical point of view [11], we propose that the linear sesquiterpenes are the precursors of the bicyclic sesquiterpenes (Figure 8). Therefore, siphonodictyals B1-B3 (6-8) could be derived from siphonodictyals E1-E3 (1-3), respectively.

Table 4: Results of the antimicrobial and antiproliferation assays of compounds 1-5. Minimum inhibiting concentrations (MIC) for the antimicrobial assays and the $\mathrm{IC}_{50}$ values for the antiproliferation assays are given in $\mu \mathrm{M}$.

\begin{tabular}{|c|c|c|c|c|c|c|}
\hline & & 1 & 2 & 3 & 4 & 5 \\
\hline \multirow[t]{2}{*}{ Gram-negative bacteria } & Pseudomonas aeruginosa & - & - & - & - & - \\
\hline & Klebsiella pneumonia & - & - & - & - & - \\
\hline \multirow[t]{3}{*}{ Gram-positive bacteria } & Staphylococcus aureus (MRSA) & - & - & 37 & - & 117 \\
\hline & Staphylococcus aureus (MSSA) & - & - & 74 & - & 117 \\
\hline & Micrococcus luteus & - & - & 74 & - & 58 \\
\hline Fungi & Candida albicans & - & - & - & - & - \\
\hline \multirow[t]{4}{*}{ Cytotoxic activity } & L929 mouse fibroblasts & - & - & - & 27 & - \\
\hline & KB31 epidermoid carcinoma & - & - & - & 108 & - \\
\hline & MCF7 breast cancer & - & - & - & 54 & 175 \\
\hline & FS4-LTM conditional immortalization human fibroblasts & - & - & - & - & - \\
\hline
\end{tabular}

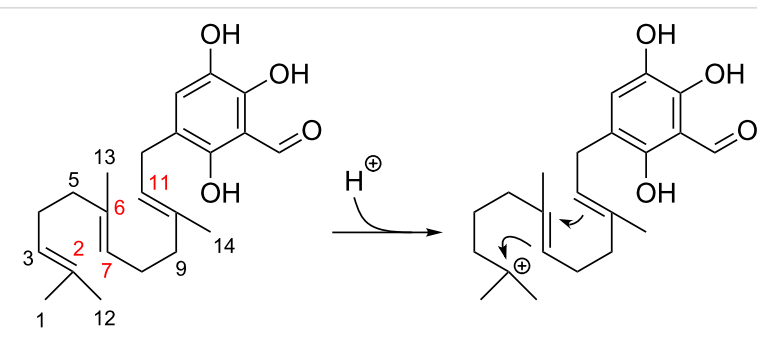

siphonodictyal E derivative<smiles>CC1CCC2C(C)(C)CCC[C@]2(C)/C1=C\c1cc(O)c(O)c(C=O)c1O</smiles><smiles>CCCC</smiles>

siphonidictyal B

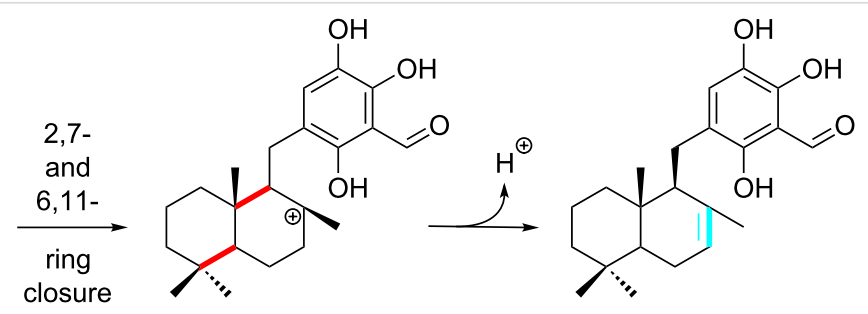

siphonodictyal C

Figure 8: Hypothetical biogenesis of the bicyclic sesquiterpenoid moiety from the acyclic precursor of the siphonodictyals in the sponge Aka coralliphagum [11]. The newly formed bonds from the acyclic to the bicyclic sesquiterpenoid moiety are drawn in red. The isomerizing double bond is drawn in blue. 
Aromatic sulfates occur in a wide range of higher plants and animals, particularly those growing in marine, estuarine, or freshwater environments. This is probably due to the high content of inorganic sulfate in aquatic environments (both limnic and marine environments - seawater contains an average of $28.7 \mathrm{mM}$ inorganic sulfate [12]). Jensen and Ragan have demonstrated the presence of the natural product 1,2,3,5tetrahydroxybenzene-2,5-disulfate in the marine brown alga Ascophyllum nodosum [13]. Kobayashi et al. isolated halenaquinol sulfate from the marine sponge Xestospongia sapra [14].

In the course of our investigation on the sponge Aka coralliphagum, we isolated a number of compounds containing sulfated phenols. These sulfated metabolites are labile [5], and easily loose the sulfate ester groups by hydrolysis in water [15]. Moreover, the influence of the sulfate esters on the bioactivity has been proven by activity tests: the desulfated compounds tend to be more active [5]. Therefore, we propose that the sulfate esters act as hydroxy protecting groups. The sponges excrete the sesquiterpene hydroquinones primarily in the sulfated form and their activities get increased by hydrolysis of these labile groups. This would lead to a prolonged bioactivity of these metabolites and therefore to a more efficient defense against predators or pathogens.

\section{Experimental}

${ }^{1} \mathrm{H}$ and ${ }^{13} \mathrm{C}$ NMR spectra were recorded on a Bruker Avance $600 \mathrm{MHz}$ NMR spectrometer equipped with a cryo platform and a Bruker Avance $400 \mathrm{MHz}$ NMR spectrometer. All experiments were measured at $303 \mathrm{~K}$. HPLC separation was achieved by a Kromasil RP-18 column $(16 \mathrm{~mm} \times 250 \mathrm{~mm}$,

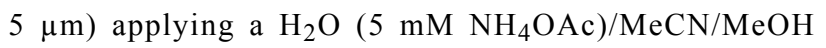
gradient. UV spectra were recorded during HPLC separation with a DAD detector (Jasco MD-2010 Plus). Accurate mass spectra were acquired using a Bruker micrOTOF $_{\text {LC }}$ mass spectrometer equipped with an ESI source. Mass calibration was performed using a sodium formate cluster prior each experiment.

The sponges were collected by SCUBA diving at a depth of $29 \mathrm{~m}$ off the coast of San Salvador in the Bahamas in June 2008. The samples were immediately frozen after collection and kept at $-20{ }^{\circ} \mathrm{C}$ until extraction. A voucher specimen of this species is deposited in our lab (voucher number: $A K A$ 08/45). The freeze-dried sponge sample (107.6 g) was extracted three times at room temperature with $\mathrm{DCM} / \mathrm{MeOH}(1: 1)$. After filtration, the filtrate was evaporated to yield $35.5 \mathrm{~g}$ crude extract which was further partitioned between $n$-hexane and methanol. The methanol extract was dried and followed with the partitioning between $n$ - $\mathrm{BuOH}$ and $\mathrm{H}_{2} \mathrm{O}$. The resulting $n-\mathrm{BuOH}$ phase was concentrated ( $9.2 \mathrm{~g}$ ) and purified by liquid chromatography using RP-18 silica gel with a stepwise gradient from $\mathrm{H}_{2} \mathrm{O} / \mathrm{MeOH}$ (100:0), (85:15), (50:50) to (0:100) yielding fractions $\mathrm{A}, \mathrm{B}, \mathrm{C}$, and $\mathrm{D}$, respectively. The fraction $\mathrm{B}$ was further purified by HPLC using an RP-18 column yielding compounds 1 (2.2 mg, HPLC gradient flow: $\mathrm{H}_{2} \mathrm{O}\left(5 \mathrm{mM} \mathrm{NH}_{4} \mathrm{OAc}\right) / \mathrm{MeCN}$ : $0 \mathrm{~min} 81: 19,40 \mathrm{~min}$ 75:25), 2 (3.1 $\mathrm{mg}$, HPLC isocratic flow: $\mathrm{H}_{2} \mathrm{O}$ (5 mM NH $\left.4 \mathrm{OAc}\right) / \mathrm{MeCN}:$ 87:13 $\left.40 \mathrm{~min}\right), 4$ (1.3 mg, HPLC gradient flow: $\mathrm{H}_{2} \mathrm{O}\left(5 \mathrm{mM} \mathrm{NH} \mathrm{HAc}_{4} \mathrm{OAeCN}\right.$ : 0 min $85: 15$,

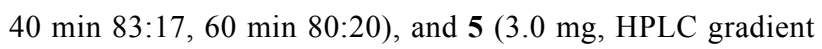
flow: $\mathrm{H}_{2} \mathrm{O}\left(5 \mathrm{mM} \mathrm{NH}_{4} \mathrm{OAc}\right) / \mathrm{MeCN}$ : 0 min 85:15, $40 \mathrm{~min}$ $83: 17,60 \mathrm{~min} 80: 20)$. The fraction $\mathrm{C}$ was also further purified by HPLC using the same RP-18 column yielding 3 ( $2.5 \mathrm{mg}$, HPLC gradient flow: $\mathrm{H}_{2} \mathrm{O}\left(5 \mathrm{mM} \mathrm{NH} \mathrm{H}_{4} \mathrm{OAc}\right) / \mathrm{MeCN}: 0 \mathrm{~min}$ $76: 24,40 \min 74: 26,45 \min 70: 30)$

\section{Antimicrobial assay}

Determination of antimicrobial activities was carried out by the Helmholtz Center for Infection Research (HZI), and was based on the microdilution test, using 96-well micro titration plates. The MIC was defined as $50 \%$ growth inhibition after 24 hour incubation compared to that in the growth control well.

\section{Cytotoxic assay}

The cytotoxicity was determined using WST-1 assays, targeting cell lines L929 mouse fibroblasts, KB-31 epidermoid carcinoma, MCF-7 breast cancer, and FS4-LTM conditional immortalization human fibroblasts, respectively. The FS4-LTM cell line was incubated for 24 hours with the tested substances. The other cell lines were incubated for 5 days with the tested substances.

\section{Experimental data}

Siphonodictyal E1 (1): yellow powder; ${ }^{1} \mathrm{H}$ NMR (DMSO- $d_{6}$, $600 \mathrm{MHz}$ ) and ${ }^{13} \mathrm{C}$ NMR (DMSO- $d_{6}, 150 \mathrm{MHz}$ ) see Table 1; HRMS-ESI(-) $m / z:[\mathrm{M}+\mathrm{Na}-2 \mathrm{H}]^{-}$calcd for $\mathrm{C}_{24} \mathrm{H}_{33} \mathrm{NO}_{11} \mathrm{~S}_{2} \mathrm{Na}$, 598.1398; found, 598.1338.

Siphonodictyal E2 (2): yellow powder; ${ }^{1} \mathrm{H}$ NMR (DMSO- $d_{6}$, $600 \mathrm{MHz}$ ) and ${ }^{13} \mathrm{C}$ NMR (DMSO- $d_{6}, 150 \mathrm{MHz}$ ) see Table 1; HRMS-ESI(-) $m / z$ : $[\mathrm{M}-\mathrm{H}]^{-}$calcd for $\mathrm{C}_{22} \mathrm{H}_{29} \mathrm{O}_{9} \mathrm{~S}, 469.1538$; found, 469.1561 .

Siphonodictyal E3 (3): yellow powder; ${ }^{1} \mathrm{H}$ NMR (DMSO- $d_{6}$, $600 \mathrm{MHz}$ ) and ${ }^{13} \mathrm{C}$ NMR (DMSO- $d_{6}, 150 \mathrm{MHz}$ ) see Table 1 ; HRMS-ESI(-) $m / z$ : $[\mathrm{M}+\mathrm{Na}-2 \mathrm{H}]^{-}$calcd for $\mathrm{C}_{22} \mathrm{H}_{28} \mathrm{O}_{10} \mathrm{~S}_{2} \mathrm{Na}$, 539.1027; found, 539.1046 .

Siphonodictyal E4 (4): yellow powder; $\mathrm{CD}$ data $\{(\mathrm{MeOH})$ $\left.[\theta]_{291}^{\max }=+37\right\} ;{ }^{1} \mathrm{H}$ NMR (DMSO- $\left.d_{6}, 600 \mathrm{MHz}\right)$ and ${ }^{13} \mathrm{C} \mathrm{NMR}$ $\left(\right.$ DMSO- $d_{6}, 150 \mathrm{MHz}$ ) see Table 1; HRMS-ESI(-) $\mathrm{m} / z$ : [M + 
$\mathrm{Na}-2 \mathrm{H}]^{-}$calcd for $\mathrm{C}_{22} \mathrm{H}_{28} \mathrm{O}_{11} \mathrm{~S}_{2} \mathrm{Na}$, 555.0976; found, 555.0954

Cyclosiphonodictyol A (5): colorless powder; CD data $\left\{(\mathrm{MeOH})[\theta]_{295}^{\max }=+163\right\} ;{ }^{1} \mathrm{H}$ NMR (DMSO- $\left.d_{6}, 600 \mathrm{MHz}\right)$ and ${ }^{13} \mathrm{C}$ NMR (DMSO-d, $150 \mathrm{MHz}$ ) see Table 1; HRMS$\mathrm{ESI}(-) \mathrm{m} / z$ : $[\mathrm{M}-\mathrm{H}]^{-}$calcd for $\mathrm{C}_{22} \mathrm{H}_{31} \mathrm{O}_{3}, 343.2279$; found, 343.2292 .

\section{Supporting Information}

\section{Supporting Information File 1}

$1 \mathrm{D}$ and 2D NMR spectra of the isolated compounds.

[http://www.beilstein-journals.org/bjoc/content/

supplementary/1860-5397-10-52-S1.pdf]

\section{Acknowledgements}

Financial support from the Deutsche Forschungsgemeinschaft (DFG) under grants Ko 1314/5-1 and 5-2 (DFG research unit FOR 934) is gratefully acknowledged. Sponge collection was carried out by Dr. Gesine Schmidt and Dr. Achim Grube during a scientific expedition to the Bahamas in 2008. We would like to acknowledge the support of Prof. Dr. Joseph R. Pawlik (University of North Carolina, Wilmington, USA) who gave members of the Köck research group the opportunity to participate in the research trips to the Bahamas for the time period from 1998 to 2008. We further thank Dr. Sven Zea (Universidad Nacional de Colombia) for identification of the sponge samples as well as Dr. Florenz Sasse and Dr. Galina Sergeev (HZI Braunschweig) for carrying out the bioassays.

\section{References}

1. Rützler, K. Smithsonian Contrib. Zool. 1971, 77, 1-37. doi:10.5479/si.00810282.77

2. Sullivan, B. W.; Faulkner, D. J.; Matsumoto, G. K.; He, C. H.; Clardy, J. J. Org. Chem. 1986, 51, 4568-4573. doi:10.1021/jo00374a015

3. Sullivan, B. W.; Faulkner, D. J. New Perspectives in Sponge Biology. Third International Sponge Conference, Woods Hole, Massachusetts, Nov 17-23, 1985; Smithsonian Institution Press: Washington, DC, 1985; pp 45-50.

4. Sullivan, B.; Djura, P.; Mcintyre, D. E.; Faulkner, D. J. Tetrahedron 1981, 37, 979-982. doi:10.1016/S0040-4020(01)97672-0

5. Grube, A.; Assmann, M.; Lichte, E.; Sasse, F.; Pawlik, J. R.; Köck, M. J. Nat. Prod. 2007, 70, 504-509. doi:10.1021/np0603018

6. Couperus, P. A.; Clague, A. D. H.; van Dongen, J. P. C. M. Org. Magn. Reson. 1976, 8, 426-431. doi:10.1002/mrc.1270080807

7. Coates, R. M.; Ley, D. A.; Cavender, P. L. J. Org. Chem. 1978, 43, 4915-4922. doi:10.1021/jo00420a003

8. Ragan, M. A. Can. J. Chem. 1978, 56, 2681-2685. doi:10.1139/v78-441

9. Kalinowski, H.-O.; Berger, S.; Braun, S. ${ }^{13}$ C NMR-Spektroskopie; Georg Thieme Verlag: Stuttgart, 1984; pp 685 ff.
10. Killday, K. B.; Wright, A. E.; Jackson, R. H.; Sills, M. A. J. Nat. Prod. 1995, 58, 958-960. doi:10.1021/np50120a024

11. Fontana, A.; Tramice, A.; Cutignano, A.; d'Ippolito, G.; Gavagnin, M.; Cimino, G. J. Org. Chem. 2003, 68, 2405-2409. doi:10.1021/jo026131v

12. Zehnder, A. J. B.; Zinder, S. H. The Sulfur Cycle. In The Handbook of Environmental Chemistry; Hutzinger, O., Ed.; Springer: Berlin, 1980; Vol. 1A, pp 105-145.

13. Jensen, A.; Ragan, M. A. Tetrahedron Lett. 1978, 19, 847-850. doi:10.1016/S0040-4039(01)85415-0

14. Kobayashi, M.; Shimizu, N.; Kyogoku, Y.; Kitagawa, I. Chem. Pharm. Bull. 1985, 33, 1305-1308. doi:10.1248/cpb.33.1305

15. Benkovic, S. J. J. Am. Chem. Soc. 1966, 88, 5511-5515. doi:10.1021/ja00975a027

\section{License and Terms}

This is an Open Access article under the terms of the Creative Commons Attribution License

(http://creativecommons.org/licenses/by/2.0), which permits unrestricted use, distribution, and reproduction in any medium, provided the original work is properly cited.

The license is subject to the Beilstein Journal of Organic Chemistry terms and conditions: (http://www.beilstein-journals.org/bjoc)

The definitive version of this article is the electronic one which can be found at: doi: $10.3762 /$ bjoc. 10.52 